https://dx.doi.org/10.4314/ijs.v19i2.7

Ife Journal of Science vol. 19, no. 2 (2017)

\title{
FRESHWATER DIATOMS DIVERSITY OF NATIONAL PARKS IN NIGERIA I: OKOMU NATIONAL PARK, SOUTH-SOUTH, NIGERIA.
}

\author{
Adesalu, Taofikat Abosede. \\ Department of Botany, Faculty of Science, University of Lagos, Nigeria \\ boseadesalu@yahoo.com; tadesalu@unilag.edu.ng \\ (Received: $1^{\text {st }}$ December, 2016; Accepted: $28^{\text {th }}$ September, 2017)
}

\section{ABSTRACT}

\begin{abstract}
This study represents the first taxonomic and ecological description of the diatom flora of water and sediments in two freshwater lakes within Okomu National Park Edo State, Nigeria, using light and scanning electron microscopy (SEM). Twenty-nine species of diatoms belonging to fifteen genera, Achnanthes, Achnanthidium, Chamaepinnularia, Cymbella, Discotella, Eolimna, Eunotia, Frustulia, Gomphonema, Luticola, Nitzschia, Pinnularia, Placoneis Sellaphora and Stauroneis were identified. The taxa were dominated by Eunotia spp. Water pH of 5.9-6.3 and surface temperature of $28{ }^{\circ} \mathrm{C}$ probably implies that the diatoms especially Eunotia spp are exploring an ecological niche that is probably favourable for its growth. Okomu National Park appears to be a hotspot for Eunotia species diversity, and further study of the oligotrophic waters of this site is recommended.
\end{abstract}

Keywords: Diatom, Diversity. Freshwater, National Park, Okomu, Season, Tropical.

\section{INTRODUCTION}

Diatoms are single-celled algae and the most common phytoplankton with their cell walls made of silica (Wehr and Sheath, 2003). According to Silva et al. (1994), Ruhland et al. (2003), and Perera and Yatigammana (2015), diatoms are diverse eukaryotic unicellular microorganisms characterized by siliceous cell walls. Their ecological diversity is reflected by their occurrence in almost all aquatic habitats, where they play an important role as primary producers and in geochemical cycling of various naturally occurring elements, in particular carbon and silicon (Perera and Yatigammana, 2015). Diatoms grow abundantly in rivers, colonising almost all suitable habitats. They have been used extensively in studies related to the monitoring of water quality (Round, 1991). Diatoms can help build healthy stream environments by stabilizing the substrata and providing food and habitat for other biota within the ecosystem. Without diatoms and benthic algae, the stream ecosystem could become dysfunctional and collapse (Blinn and David, 2003) because diatoms can also tolerate variable environmental conditions, which make them extremely valuable in determining environmental disturbances by comparing pristine ecosystems versus impacted (Blinn and David, 2003). Diatoms are responsible for as much as $20 \%$ of carbon fixation globally by means of photosynthesis. This process of cycling materials through the areolae is what characterizes diatoms as excellent components for nutrient recycling and uptake (Ellie, 2014). The density and the diversity of phytoplankton are biological indicators for evaluating water quality and the degree of eutrophication (Shekhar et al., 2008). Some national parks diatoms that have been documented elsewhere in the world include, Spaulding et al. (2008) on stalk forming diatoms in Grand Teton national park Wyoming, Hobbs et al. (2009) on epipelic diatoms from Yellowstone national park Wyoming, Bartozek et al. (2013) gave report of eighty four diatoms from Iguaçu National Park in Brazil, Zhang et al. (2016) documented Oricymba xianjuensis sp. nov. in Xianju national park, China, Veselá and Johansen (2014) reported three new Eunotia spp from Acadia National park Maine while Ortiz-Lerin and Cambra (2007) discussed the distribution and taxonomy of 397 epilithic diatoms notes in rivers and streams of Northern Spain. In Nigeria, algological studies on lotic system are gaining interest but necessarily that of national parks and include that of Kadiri and Azomani (2000) who studied the effect of brewery effluent on the growth of two chlorophytes in Ikpoba River, Kadiri and Omozusi (2002) reported the phytoplankton of River Okhuahe in Benin, Kadiri (2007) reported the phytoplankton of River Ethiope. Most recent phycological information in similar freshwater bodies are available in Akoma and Opute (2010), Adesalu and Nwankwo (2010, 2012), Alika and Akoma (2012), Adesalu et al. 
(2010, 2016a, 2016b), Ekhator et al. (2014, 2015), Adesalu (2016), Adesalu and Kunrunmi (2016), Akinyemi and Adesalu (2016). Of all mentioned work above, Okomu National Park water bodies and several other national parks except River Oli in Kainji Lake National park (Adesalu, 2010) water bodies remain without phycological information hence such studies remain important because majority of the riverine inhabitant most of the time, depend on their surrounding water (River) apart from rain water for their water needs. In this work, scanning electron micrographs of the most common species were also presented. The author hopes this will facilitate future taxonomic work.

\section{MATERIALS AND METHODS}

Description of study site

The Okomu National Park, (Figure 1) formerly known as the Okomu Wildlife Sanctuary, is a forest block within the $1,082 \mathrm{~km}^{2}$ Okomu Forest Reserve in the Ovia South-West Local Government Area of Edo State in Nigeria (Birdlife International, 2016). The park is about 40 $\mathrm{km}$ West of Benin City (Williams 2008). The park holds a small fragment of the rich forest that once covered the region, and is the last habitat for many endangered species. It continues to shrink as villages encroach on it, and is now less than one third of its original size. The park holds a remnant of the Nigerian lowland forests that once formed a continuous $50-100 \mathrm{~km}$ wide belt from the Niger River west to the Dahomey Gap in Benin. The south and south-east of the forest is separated from the coast by mangrove and swamp forests, while to the north it merged into the Guinean Forest-Savanna Mosaic ecoregion. The park is drained by the Osse River which defines its eastern boundary. The Okomu River forms the western boundary. Among the common trees are Kapok, Celtis zenkeri, Triplochiton scleroxylon, Antiaris africana, Pycnanthus angolensis and Alstonia congoensis (Birdlife International, 2016). The park is probably the best example of mature secondary forest in south-west Nigeria. The park is accessible to tourists and has well marked trails.

\section{Collection of sample}

The study was based on a single sampling strategy during one week field trips to Okomu National Park, Edo state. Samples were collected on 25
April, 2015 from two locations each from two lakes called Lake 36 (N06 ${ }^{\circ} 23^{\prime}$ 056; E005 21' 165; $\left.\mathrm{N} 06^{\circ} 23^{\prime} 063 ;{\mathrm{E} 005^{\circ}}^{\circ} 21^{\prime} 156\right)$ and Lake 61 (N06 $67^{\prime}$ 932; E005 37' 794; N06 $19^{\circ}$ 994; E005 $20^{\prime}$ 718). Few of the physical parameters analyzed include surface water temperature which was measured using mercury in glass thermometer, the $\mathrm{pH}$ was determined with a Phillips $\mathrm{pH}$ meter (Model PW950) while surface water conductivities and salinity were determined using HANNA instrument (H18733) and hand refractometer respectively. Biological samples were stored in $5 \mathrm{~L}$, concentrated and fixed with $4 \%$ unbuffered formalin and analyzed with the aid of Olympus XSZ-N107 photomicroscope and JOEL JSM 6060LV for scanning micrographs.

\section{Scanning Electron Microscopy preparation of the specimen and Light Microscopy}

Biological samples preserved in $4 \%$ unbuffered formalin were allowed to settle for 24 hours in the laboratory, after which the supernatant was decanted until a concentrate of $100 \mathrm{ml}$ was achieved. To facilitate diatom identification sub samples of the original collections were acidcleaned using the method suggested by Barber and Harworth (1981). A portion of the cleaned sample was added to distilled water. This slurry was filtered onto a $0.45 \mu \mathrm{m}$ Millipore type HA filter. The filters were allowed to dry. A portion of the filter was cut and mounted to an aluminum stub using adhesive carbon tape. The aluminum stub was sputter coated with $20 \mathrm{~nm}$ of gold or goldpalladium. All scanning electron microscope observations were performed with a JOEL JSM 6060LV using a $10 \mathrm{kV}$ accelerating voltage at $\mathrm{St}$. Cloud State University, U.S.A. Description of some taxa frustule structures, valve sizes (diameter, length, width), number of striae/10 $\mu \mathrm{m})$ and other taxonomic data were extracted from previous literatures of Ort'iz-Ler'in and Cambra (2007) and Diatoms of United States (Online) accessed on the stated dates. This was necessary for proper understanding of the taxa. For photomicrographs, taxanomic keys employed in the identification included Hustedt (1930); Patrick and Reimer (1966, 1975); Prescott (1982); Krammer and Lange-Bertatot (1991); Whitford and Schumacher (1973), Metzeltin and Witkowski (1996), Lange-Bertalot and Metzeltin (1996). 


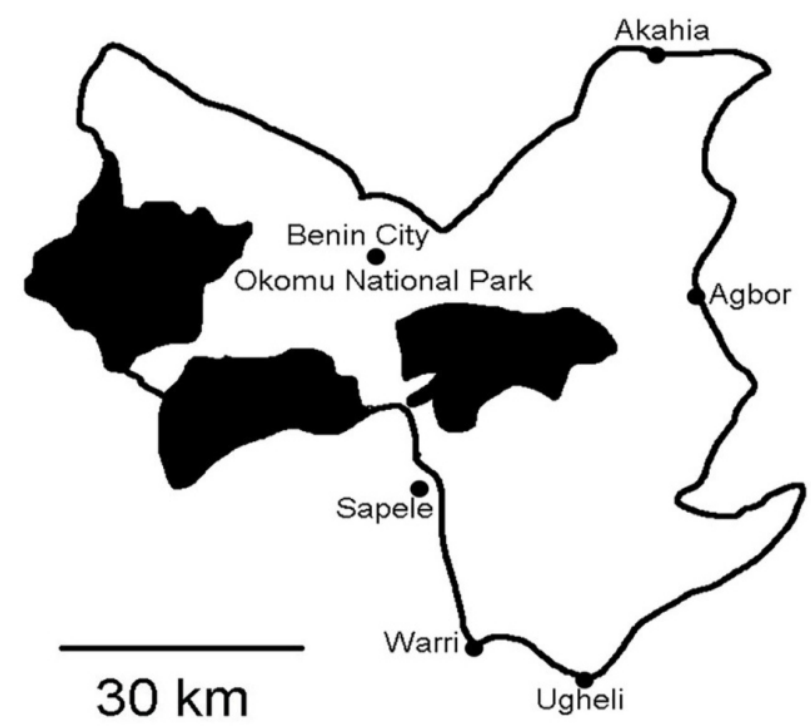

Figure 1: Parts of Edo state map showing Okomu National Park and its environs.

\section{RESULTS}

The diatom composition of Okomu National Park is shown in table 1, a total of 29 diatom taxa belonging to 15 genera with more pennate forms than centric diatoms were observed. Out of the 15 genera, Discotella species was the only centric diatom observed. The pennate form which was dominated by Eunotia species include Eunotia faba Ehr.; E. glacialis Meister; E.incisa W. Smith ex.W.Gregory; E. intermidia (Krasske) Nörpel and Lange-Bertalot; E. minor (Kützing) Grunow; E. monodon Ehr.; Eunotia pectinalis (Kützing) Rabenh and E. subarcuatoides Alles, Nörpel and LangeBertalot (Figures 2 and 3) followed by Pinnularia species which recorded four; Pinnularia brannii (Grunow) Cleve; P. brevicostata Cleve; P. gibba Ehr. and P. microstauron (Ehr.) Cleve (Plate 3). Other species include Achnanthidium minutissimum (Kützing ) Czarnecki; Gomphonema parvulum (Kützing) Kützing; Frustulia rhomboides (Ehr.); Placoneis gastrum (Ehrenberg) Mereschkowsky; Sellaphora sp.; Eolimna minima (Grunow) LangeBertalot and W.Schiller; Chamaepinnularia mediocris (Krasske) Lange-Bertalot in Lange-Bertalot and Metzeltin; Luticola sp. and Achnanthes sp. (Figures 4 and 5). Nitsschia sigma (Kützing) W. Smith and Stauroneis anceps Ehr. 
Table 1: Taxonomic classification of diatom flora at the Okomu National Park, Nigeria.

\begin{tabular}{|c|c|}
\hline & Division: Bacillariophyta \\
\hline & Class: Bacillariophyceae \\
\hline & Order: Stephanodiscales \\
\hline & Family: Stephanodiscaeae \\
\hline 1 & Discotella sp. \\
\hline & Order: Mastogloiales \\
\hline & Family: Achnanthaceae \\
\hline 2 & Achnanthes sp.I \\
\hline 3 & Achnanthes sp.II \\
\hline & Order: Cymbellales \\
\hline & Family: Cymbellaceae \\
\hline 4 & Cymbella sp \\
\hline & Family: Gomphonemataceae \\
\hline 5 & Gomphonema parvulum \\
\hline 6 & Placoneis sp. \\
\hline & Order: Cocconeidales \\
\hline & Family: Achnanthidiaceae \\
\hline 7 & Achnanthidium minutissimum (Kützing) Czarnecki \\
\hline & Order: Eunotiales \\
\hline & Family: Eunotiaceae \\
\hline 8 & Eunotia faba Ehr. \\
\hline 9 & E. glacialis Meister \\
\hline 10 & E.incisa W.Smith ex.W.Gregory \\
\hline 11 & E. intermidia (Krasske) Nörpel and Lange-Bertalot \\
\hline 12 & E. minor (Kützing) Grunow \\
\hline 13 & E. monodon Her \\
\hline 14 & Eunotia pectinalis (Kützing) Rabenh \\
\hline 15 & E. subarcuatoides Alles, Nörpel and Lange-Bertalot \\
\hline 16 & Eunotia sp. I \\
\hline 17 & Eunotia sp.II \\
\hline & Order: Naviculales \\
\hline 18 & $\begin{array}{l}\text { Chamaepinnularia mediocris (Krasske) Lange-Bertalot in Lange- } \\
\text { Bertalot and Metzeltin }\end{array}$ \\
\hline 19 & Eolimna minima (Grunow) Lange-Bertalot and W.Schiller \\
\hline & Family: Amphipleuraceae \\
\hline 20 & Frustulia rhomboides (Ehr.) De Toni \\
\hline & Family: Diadesmidiaceae \\
\hline
\end{tabular}


Description of some of the taxa

Eunotia pectinalis (Dillwyn, O. F. Müller),

Kützing) Rabenhorst 1864

Krammer and Lange-Bertalot 1991, 193, Fig.

141: 1-7, Fig. 143: 1. Metzeltin and Witkowski

1996, 98, Fig. 33:1; Lange-Bertalot and Metzeltin 1996, 146, Fig. 14: 5-7.

(Figure $2 \mathrm{~A}$ and $\mathrm{B}$ )

As described by Krammer and Lange-Bertalot (1991) and cited by Ortiz-Lerin and Cambra (2007), Frustules rectangular in girdle view. Valve elongates, slightly curved or bent. Ventral margin straight or slightly concave, sometimes slightly swollen at the centre of the valve. Valve narrowed toward broadly attenuated, truncate rounded ends. Striae parallel, slightly radiate at the ends. Striae: $7-12 / 10 \mu \mathrm{m}$ at the centre of the valve, to 14 in $10 \mu \mathrm{m}$ at the ends of the valve.

Eunotia monodon Ehrenberg 1843

Krammer and Lange-Bertalot 1991, 210, Fig.

158:1-6.

(Figure $2 \mathrm{C}$ and D)

Ventral margin usually strong with short shells, forms with a hump in the middle. Dorsal edge most strongly convex, margin often parallel to ventral in the middle part, gradually declining and in front of the ends sometimes weakly drawn in. Terminal nodes and simply arched distal raphe close to the pole.

Eunotia subarcuatoides E. Alles, M. Nörpel andLange-Bertalot 1991

Krammer and Lange-Bertalot 1991, 214, Fig.

138: 1-9, Fig. 145:6.

(Figure 2E)

Narrow linear in girdle view. Valves slender, bowshaped, as a rule strongly curved, with more or less parallel margins. The dorsal line somewhat strongly sloping toward the ends, valves therefore slightly narrowed towards the end; ends rounded. End nodules small, raphe slightly developed. Small forms, rarely over $30 \mu \mathrm{m}$ long, strongly narrowed near the ends. Valves therefore strongly lanceolate, often only weakly bent. Striae: 1823/10 $\mu \mathrm{m}$. (Ortiz-Lerin and Cambra 2007).

Eunotia intermedia (Krasske ex Hustedt) Nörpel and Lange-Bertalot 1991

Krammer and Lange-Bertalot 1991, 215,
Fig.143: 10-15.

(Figure $2 \mathrm{~F}$ and $\mathrm{H}$ )

Ventral margin straight, wall thickened in areas halfway between the centre of the valve and the ends. Dorsal margin convex. Ends not distinctly formed, but confluent with the rest of the valve. Terminal nodules distinct, near the ends of the valve. Striae parallel, $14-16 / 10 \mu \mathrm{m}$ at the center of the valve, more numerous toward the ends (OrtizLerin and Cambra 2007).

\section{Eunotia glacilais Meister 1912}

Krammer and Lange-Bertalot 1991, 207, Fig. 151:1-10A.

(Fig 2. I)

Frustule in girdle view, broad, rectangular with few bends, proximal raphe of a long and relatively wide hyaline area, ventral margin concave, dorsal margin parallel or slightly convex, gradually declining, the ends are slightly narrowed to slightly distended, bluntly rounded and usually bent posteriorly. Length (15) 30 approximately $200 \mu \mathrm{m}$.

\section{Eunotia minor (Kützing) Grunow in Van}

Heurck 1881

Krammer and Lange-Bertalot 1991, 196,

Fig.142: 7-15, Fig. 144: 5

(Figure 2J)

Cells in girdle view thick, rectangular; laterally asymmetrical (lunate) in valve view along the apical axis. Valves bent with sub-rostrate large round apices. Ventral margin slightly concave but slightly inflated at the centre; dorsal margin convex. Striae uniseriate, on the ventral mantle more numerous and alternating, 9-15/10 $\mu \mathrm{m}$.

\section{Eunotia faba Ehrenberg1838}

Krammer and Lange-Bertalot 1991, 225, Fig. 164:1-10.

(Figure 3A)

Bahls (2014) described Eunotia faba valves as asymmetric to the apical axis and variably asymmetric to the transverse axis. Dorsal margins are moderately arched. Ventral margins are weakly concave. The apices are broadly rounded, with a deep notch on the ventral side. Helictoglossae are removed some distance from the apices. Terminal raphe fissures are very short at the junction of the valve face and mantle. Striae are radiate and very finely punctate. Forked, or short, costae occur along the dorsal margin in some specimens. 
Areolae are difficult to resolve in LM and number 30-35 in $10 \mu \mathrm{m}$ (Bahls, 2014).

Eunotia incisa Gregory 1854

Krammer and Lange-Bertalot 1991, 221, Fig.161: 8-19, Fig. 162: 1-2, Fig. 163: 1-7

(Figure 3B)

According to Krammer and Lange-Bertalot 1991 as cited by Ortiz-Lerin and Cambra (2007), this species is characterized by the apices of the valve undifferentiated from the main body of the valve and by the very fine striae. Frustules in girdle view are rectilinear while frustules in valve view are with straight ventral margin and convex dorsal margin. Apices of the valve usually acute, sometimes rounded. Striae have more distance at the centre of the valve than at the ends, $13-17 / 10 \mu \mathrm{m}$.

\section{Stauroneis anceps Ehrenberg 1843}

Krammer and Lange-Bertalot 1991, 240, Fig.

87:3-9, Fig. 88:2-4

(Figure $3 \mathrm{E}$ and $\mathrm{F}$ )

Stauroneis anceps valves are lanceolate to linearlanceolate. The apices are protracted and narrowly rostrate. The axial area is moderately wide and linear, expanding slightly near the central area. The central area is a narrow rectangular stauros, hardly expanded toward valve margins and sometimes with shortened striae. The raphe is lateral. Proximal raphe ends are weakly expanded, weakly deflected, and widely spaced (not extend into the central area). Striae are radiate throughout. Areolae are variably spaced and number 20-28/10 $\mu \mathrm{m}$. (Bahls, 2011).

\section{Nitzschia palea (Kützing) W. Smith 1853 \\ (Figure 3J)}

According to Kociolek (2011), Nitaschia palea valves are lanceolate with sides parallel and tapering rapidly at the poles, terminating with subcapitate apices. Fibulae are distinct, with a distinct central nodule and number $11-13$ in 10 $\mu \mathrm{m}$. Striae barely visible in LM. Striae, 36-38 /10 $\mu \mathrm{m}$ (Kociolek, 2011).

\section{Pinnularia gibba Ehrenberg 1841}

Krammer and Lange-Bertalot 1991, 423, Fig.

189:1-3,8,9.

(Figure 4A)

Tariq et al. (2006) described Pinnularia gibba valve as linear, gradually tapering to the subcapitate ends; raphe filiform with curved terminal fissures; axial area linear, widened around the central nodule; striae divergent in the middle and convergent at ends; length of frustules $75-77 \mu \mathrm{m}$ and breadth 10-13 $\mu \mathrm{m}$; striae 10-11 within $10 \mu \mathrm{m}$. (Tariq-Ali et al., 2006)

\section{Pinnulari microstauron (Ehrenberg) Cleve 1891}

Krammer and Lange-Bertalot 1991, 425, Fig.

191:1-6; Fig.192: 1-16

(Figure 4B)

As described by (Bahls 2014), valves are linear with parallel or slightly convex sides. The apices are rostrate (much narrower than the valves). The axial area is narrow and widens abruptly just short of the central area. The central area is a rhombus, which widens along the apical axis to form a variably narrow to broad transverse fascia. The slightly curved raphe is lateral, proximal raphe ends are deflected to one side and terminate with small pores. Distal raphe fissures are shaped like commas or question marks. The distal raphe fissures are surrounded by striae at the poles. Striae are strongly radiate near the valve center, becoming strongly convergent near the apices. Occasionally an isolated short striae will occur on one side of the central fascia (Bahls, 2014).

\section{Pinnularia brevicostata Cleve 1891}

Krammer and Lange-Bertalot 1991, 410, Fig. 182: 4-7, 9

(Figure 4C)

Johnson (2006) described Pinnularia brevicostata valves as linear with bluntly rounded apices. Axial area broad, one-fourth to one-half of the valve breadth. Central area a narrow bilateral fascia. Striae nearly parallel throughout most of the valve, slightly radiate at the central area, parallel to slightly convergent at the apices, 9 in $10 \mu \mathrm{m}$. Longitudinal bands indistinct, occasionally visible near the valve margin. Raphe slightly undulates. Apical raphe fissures large, "comma" shaped.

\section{Pinnularia braunii (Grunow) Cleve 1895}

Krammer and Lange-Bertalot 1991, 416, Fig. 187:1-5

(Figure 4D)

Valves linear to linear-lanceolate with slightly convex or convex margins. Valve apices usually capitate, occasionally subcapitate. Axial area narrows at the apices, becoming progressively 
broader toward the central area. Central area large, elliptical a unilateral fascia or a bilateral fascia. Striae radiate at the central area, convergent at the apices, $10-11$ in $10 \mu \mathrm{m}$. Longitudinal bands absent (Jackson 1980).

\section{Eolimna minima (Grunow) Lange-Bertalot and W.Schiller 1997}

(Figure 4G)

As described by Spaulding and Edlund (2008), the cells of Eolimna are small, generally less than 20 $\mu \mathrm{m}$ in length. A narrow central sternum is present, and the raphe is straight. Valves lack apical pore fields. SEM features show areolae are positioned medially within the frustule wall and are covered internally by hymens.

Chamaepinnularia mediocris (Krasske) Lange-Bertalot in Lange-Bertalot and Metzeltin (Figure 4H)

Described by Otu and Spaulding (2011), Chamaepinnularia mediocris have linear to broadly oval valves, with rounded apices and a gibbous middle. The axial area is narrow near the apices, becoming wider near the central area. The central area is a transverse fascia: in some specimens it extends to the valve margins, in other specimens short irregular striae are present at the margins. The raphe is filiform and slightly arched. Terminal nodules are distinct. The striae are parallel and composed of a single, elongate areola on the valve face. A smaller areola is positioned on the valve mantle. Externally, the proximal raphe ends are straight. Internally, the proximal raphe ends are slightly deflected unilaterally.

\section{Gomphonema parvulum, (Kützing) Kützing 1849}

Krammer and Lange-Bertalot 1991, 358, Fig. 154:1-25

(Figure 5A, B and C)

Valves only slightly asymmetrical to trans apical axis (heteropolar), symmetrical to apical axis. Cells box-shaped in girdle view with pseudosepta visible. Apices rounded, sub-rostrate or rostrate (occasionally sub-capitate). Raphe often slightly sinuous. A single stigma is present on one side of the central area. Striae coarse and often visibly punctate - one short stria opposite the central stigma. Striae often almost parallel. Very variable species.
Frustulia rbomboides (Ehrenberg) De Toni

Krammer and Lange-Bertalot 1991, 240, Fig. 95:1-3

(Figure 5D)

Valves rhomboidal to lanceolate, apices bluntly rounded to rostrate. Raphe central and contained in a median rib extending most of the length of the valve. At the apices, the raphe rib has the appearance of a pencil tip. Striae fine and arranged so as to produce a pattern of apical and trans apical rows (Kelly et al., 2005).

\section{Placoneis gastrum (Ehrenberg) \\ Mereschkowsky}

(Figure 5E)

Woodell (2015) described valves of Placoneis gastrum as elliptical, with broadly rounded to rostrate apices. Valves are usually slightly asymmetric to the apical axis. The axial area is narrow and the central area is irregular or transverse due to striae of variable length and arrangement. The raphe is simple, filiform, and slightly curved toward the secondary side of the valve (Woodell, 2015). The proximal raphe ends are slightly expanded. The distal raphe ends are abruptly hooked at the valve mantle. Striae are strongly radiate, curved and irregularly shortened near the central area. Striae are distinctly uniseriate, widely spaced from one another and number between 6-10 in $10 \mu \mathrm{m}$. Areolae number 24-27 in $10 \mu \mathrm{m}$ (Woodell, 2015).

\section{Acbnantbidium minutissimum (Kützing ) Czarnecki}

(Figure 5F)

Potapova (2009) described Cells of Achnanthidium minutissimum as solitary or in very short chains, often attached to substrate by a stalk. Frustules are monoraphid with a concave raphe valve and convex rapheless valve. Valves are linearlanceolate with slightly drawn-out or slightly capitate ends, $1.5-3.3 \mu \mathrm{m}$ wide, 5.6-20.8 $\mu \mathrm{m}$ long. Central external raphe ends are simple, terminal raphe fissures are short, almost straight, or absent. Internally, the central raphe ends are turned in opposite directions (Potapova 2009). Striae are radiate throughout both valves, 25-35 in $10 \mu \mathrm{m}$. Striae consist of one row of areolae. The striae are often interrupted in the central part of raphe valve to form a symmetrical or asymmetrical fascia. One row of elongated areolae is present on the valve 
mantle. External areolae openings of areolae vary in shape from circular to transapically elongated slits. Internal openings of the areolae are elliptical, occluded by hymens perforated by small pores. Girdle bands are plain, open (Potapova, 2009).

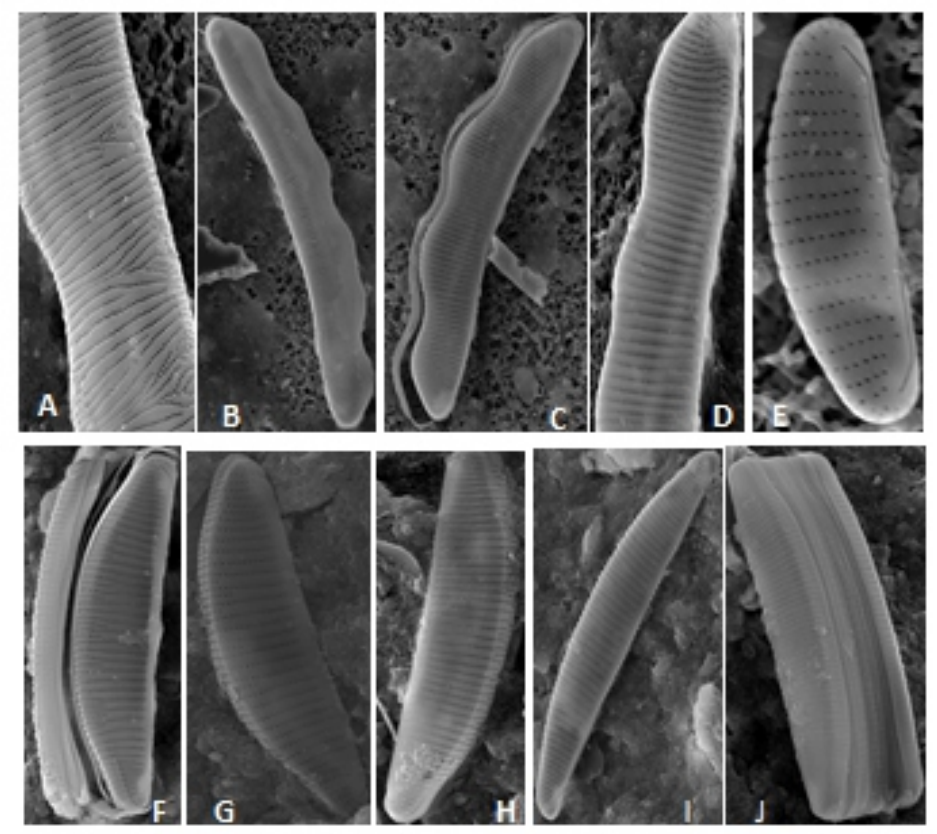

Figure 2: Valves view of scme of the Ewnotia species observed at the Olwom National Park Ewnotia pectinalis (Kützing) Rabenhorst (A and B); $E$. monodonEhr (C and D); $E$. subarcuatoides Atles, Nörpel \& Lange-Bertalot;(E); Eunotiz ivarmediz (Krassiz) Nörpel \& Lange-Bertalot (F-H); E. glacialis Meister (I) and E. minor (Kïting) Gnnow (I). Scale bar is $10 \mu \mathrm{m}$. A and D Scale bar is $5 \mu \mathrm{m}$

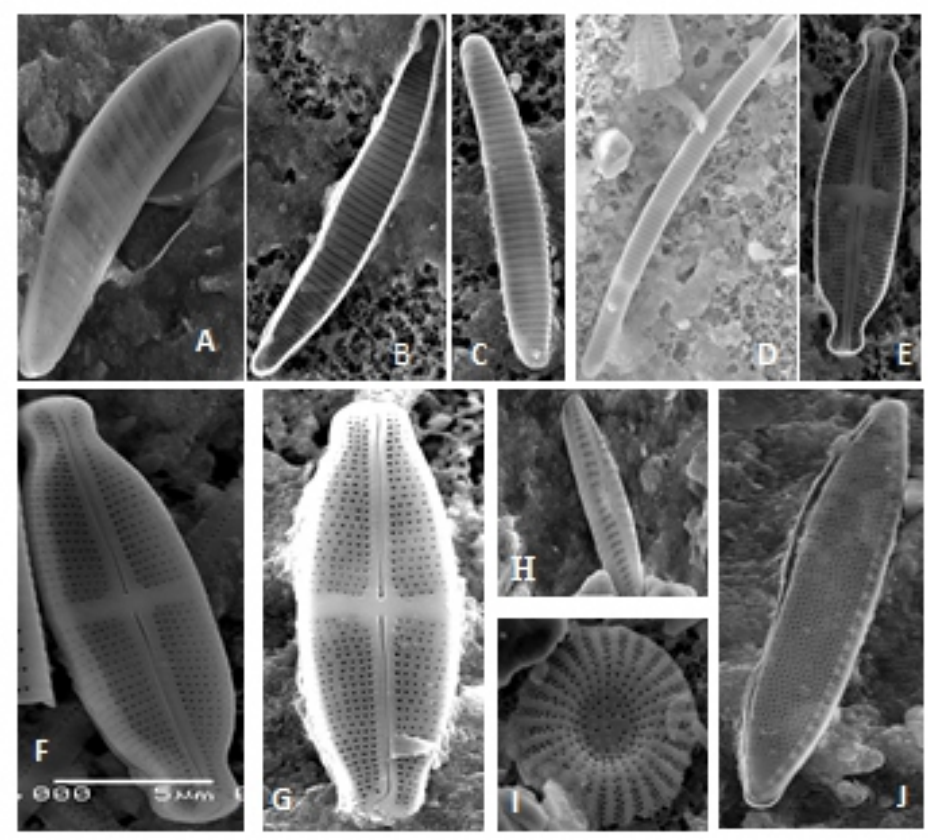

Figure 3: Ewnotia faba Ehr (A); E. incisa W.Smith ex W.Gregory (B); Ewnotia spI (C) Eunotia sp. II (D); Stawoneis areps Ehr (E and F); Staw oneis sp. (G); Cymbellasp. (H); Discotella sp. (I) and Nitzschiapaiea (Kützing)W.Smith (J)

Scale bar is 5 um 

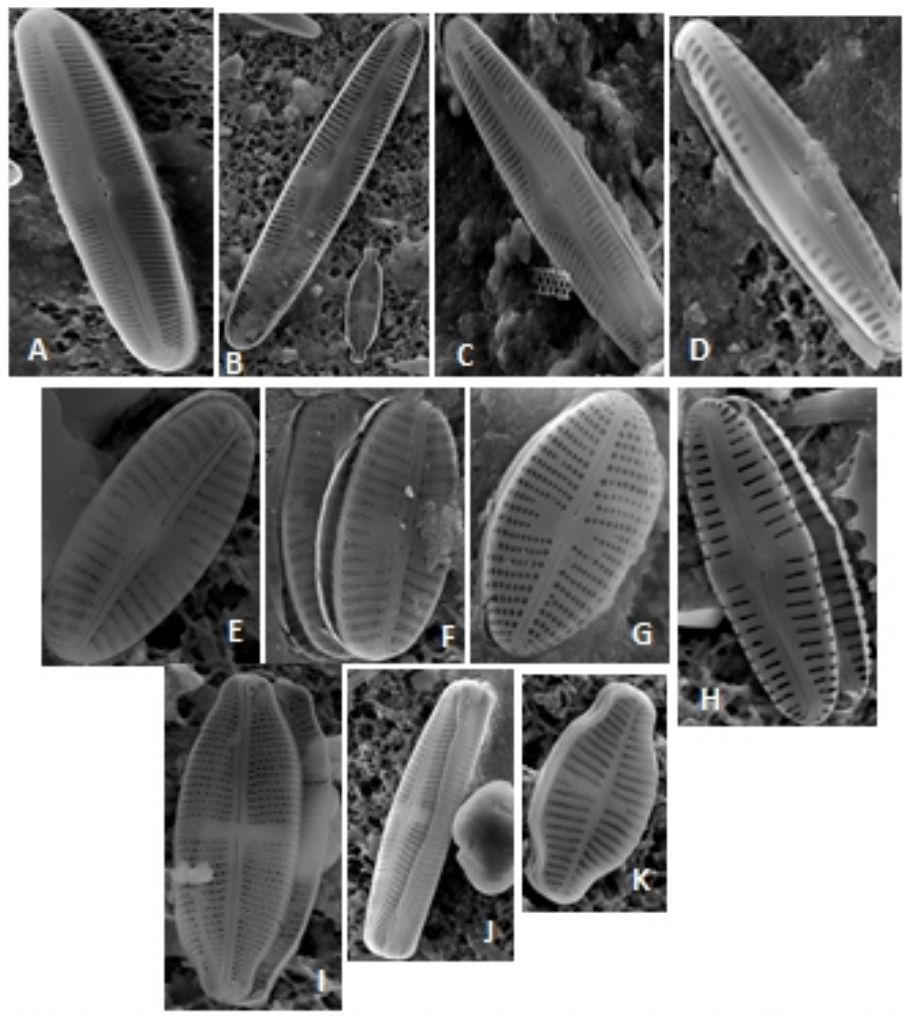

Figure 4: Pinnulavia gibba Ehr (A); P. brevicostata Cleve (B); P. microstawon(Ehr) Cleve (C); P. brawnii (Grunaw) Cleve (D); Sellophora sp (E and F); Eolinna minina (Grunow) Lange-Bertalot \& WSchiller (G); Chancepvinwacriamediocris (Kraske) Lange-Bertalot in Lange-Bertalot \& Metzeltin (H); Luticoid sp. (I); Achnconties sp. I (J)

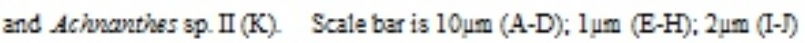
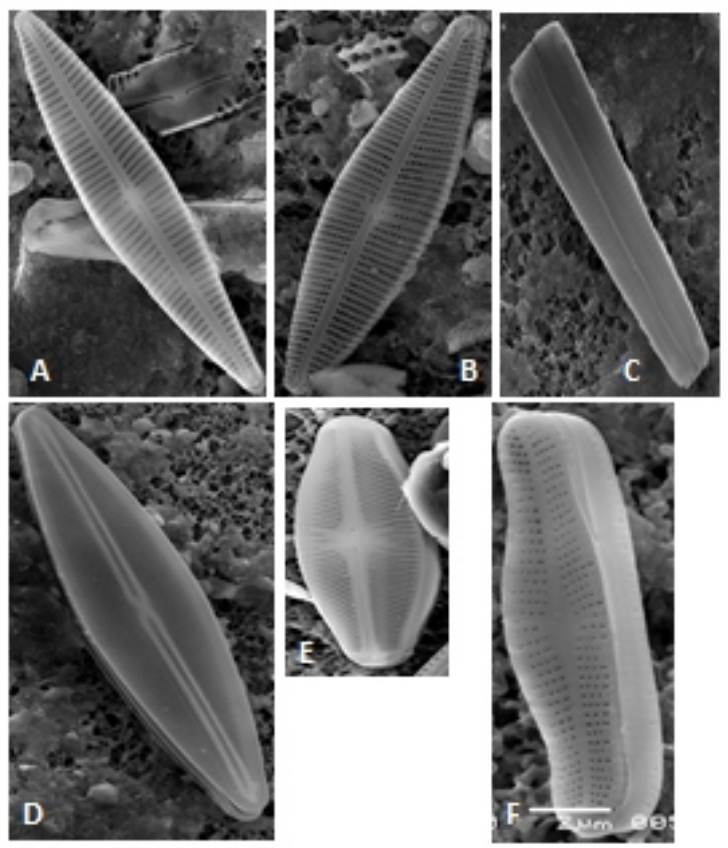

Figure 5: Gomphonema parvilun (Kütring) Kützing (A and B) valve view, G. paviliwn (C) girdle view; Frustilia riomboicess (Ehr) De Toni (D); Placones gastrun (Ehrenberg) Mereschkowsky (E); and Achnanthiơumminutissomwn (Kützing) Cramecki (F).

Scale bar is $10 \mu m$ (A-D); $2 \mu m$ (E and F) 


\section{DISCUSSION}

This report supported Pierre (1996) and OrtizLerin and Cambra (2007) who noted that Eunotia is essentially a freshwater diatom genus frequently associated with acidic waters while Ortiz-Lerin and Cambra (2007) gave taxonomic notes on Eunotia. The frequency of Eunotia species at the Okomu National park is also in conformity with the report of Alles et al. (1991) on the tolerance of Eunotia species specifically E. subarcutoides to high and strong variations of $\mathrm{pH}$ values. It is of interest to note that different species of Eunotia followed by Pinnularia dominated this seasonal water body as these organisms are considered important ecological indicators (Alles et al. 1991, Kwandrans 2007). The dominance of Eunotia over the other taxa also correlates with the result of Liu et al. (2011) who reported twenty eight taxa of Eunotia in Da'erbin Lake and Surrounding Bogs in China. According to Mayama and Kobayasi (1991); Alles et al. (1991); Levkov et al. 2000, 2005); Kwandrans (2007) and Pavlov and Levkov (2013), the restriction to the freshwater oligotrophic and oligosaprobic habitats for Eunotia is a unique ecological feature of this genus, enabling it to play an important role as an indicator of water quality monitoring. It can be said that the water body within the Okomu National park is supporting ecological growth; however since this is first attempt in documenting the microalgae taxa of this Park it is recommended that more phycological work be done in future.

\section{ACKNOWLEDGEMENT}

The author is most grateful to Professor M.L. Julius of St. Cloud State University, St. Cloud, Minnesota, United States for the use of Scanning Electron Microscope and Department of Botany, University of Lagos for providing logistics for the field trip.

\section{REFERENCES}

Adesalu, T. A. 2010. Phytoplankton dynamics of River Oli in Kainji Lake National Park, during dry season. International Journal of Botany 6(2):112-116.

Adesalu, T.A. 2016. Diversity of Green Microalgae in South-Western Lagoon, Nigeria. Journal of Sci. Res. Dev. 15(2): 1928.
Adesalu, T.A.; Bagbe, M. and Keyede, D. 2010. Hydrochemistry and phytoplankton composition of two tidal creeks in SouthWestern Nigeria. J. Trop.Biol. 58 (3): 827840.

Adesalu, T.A. and Nwankwo, D.I. 2012. Successional pattern of net phytoplankton $(>55 \mu \mathrm{m})$ in a large shallow tropical lagoon, Nigeria. J. Trop. Biol. 60(1):143-155.

Adesalu, T.A. and Kunrunmi, O.A. 2016. Diatom communities in riparian systems associated with Lagos lagoon, Nigeria 1. Seasonal and anthropogenic patterns in Majidun Creek. Algological Studies, 150: 3952.

Adesalu, T. A; Kunrunmi, O.A. and Lawal, M.O 2016a. Water quality Assessment: A case study of plankton and macrobenthic invertebrates of Porto-Novo and parts of Gulf of Guinea. Journal of Aquatic Sciences, 31(1A):39-66.

Adesalu, T. A., Kunrunmi, O.A. and Lawal, M. O. 2016b. Plankton and macrobiota communities of three tropical freshwater habitats in Ogun and Ondo states, Southwest, Nigeria. Notulae Scientia Biologicae, 8(2):246-255.

Akinyemi, S. A. and Adesalu, T. A. 2016. Composition and diversity of planktonic algae in Ikere Gorge Dam, Iseyin, Oyo state, Nigeria. Journal of Sci. Res.Dev.15(2): 29-35.

Akoma, O.C. and Opute, F.I. 2010. Phytoplankton species from Imo river estuary, Nigeria I: pennate diatoms (Diatomaceae, Eunotiaceae and Naviculaceae). Nigerian Journal of Botany 23(2):343-354.

Alika, F.O. and Akoma, O.C. 2012. Preliminary Checklist of Phytoplankton and Periphyton in River Okhuo, Nigeria. Current Research Journal of Biological Sciences 4(5): 538-543.

Bahls, L. 2011. Stauroneis anceps In Diatoms of the United States. Retrieved October 22, 2016, from http://westerndiatoms. colorado.edu/taxa/species/stauroneis_a nceps).

Bahls, L. 2014. Eunotia faba In Diatoms of the United States. Retrieved October 22, 2016, from http://westerndiatoms. 
colorado. edu/taxa/species/eunotia_faba).

Bahls, L. 2014. Pinnularia microstauron In Diatoms of the United States. Retrieved October 22, 2016, from http://westerndiatoms.colorado.edu/tax a/species/pinnularia_microstauron).

Barber, H.G and Harworth, E.Y. 1981. A guide to the morphology of the diatom frustule, with a key to the Britizsh freshwater genera. Freshwater Biological Association occasional publication. No 44.

Birdlife International 2016. Okomu National Park, Retrieved 24 August 2016.

Blinn, D. W. and David, B. H. 2003. "Use Of Diatoms and Soft Algae as Indicators of Environmental Determinants in the Lahotan Basin, USA." annual report for California State water resources board contract agreement"704558.01.ct766.

Ellie, M. 2014. "Teratological Diatom Deformities in the Periphyton of Colorado Alpine Streams as Indicators of Acid Mine Drainage Contamination". Undergraduate Honors Theses. Paper, 170pp.

Ekhator, O.; Opute, F.I. and Akoma, O.C. 2014. A Checklist of the Phytoplankton Flora of a Southern Nigerian Lotic Ecosystem. Current Research Journal of Biological Sciences 6(1):1-6.

Ekhator, O.; Denise, E.M. and Akhere, M.A. 2015. Diatom Checklist, Composition and Abundance of a Lotic Aquatic Ecosystem in Edo State, Southern Nigeria. Journal of Applied Life Sciences International3(2): 63-76.

Hobbs, W.; Alexander, P. W.; William, P. I.; Larry, A. and Kurt, O. K. 2009. Epipelic diatoms from an extreme acid environment: Beowulf Spring, Yellowstone National Park, U.S.A. Nova Hedwigia, Beiheft 135: 71-83.

Husdtedt, F. 1930. Die S"usswasser-Flora Mitteleuropas. Heft 10: Bacillariophyta (Diatomaceae). Reprint 1976, Otto Koeltz Science Publishers Königstein 466pp.

Jackson, D.C. 1980. A study of the diatom Genus Pinnularia in Iowa. Iowa State University Ph.D. Thesis 251pp.

Kadiri, M.O. 2007. Phytoplankton dynamics of a tropical river: A dry and rainy season comparison. Journal of Aquatic Sciences 22:
$11-26$.

Kadiri, M.O. and Azomani, L.I. 2000. Effect of brewery effluent into Ikpoba River on the growth of two Chlorophytes. J. Environment and Toxicology 2:14-18.

Kadiri, M.O. and Omozusi, H.I. 2002. A prepollution study of the phytoplankton of an oligotrophic river in southern Nigeria. Afr. J.Environ. Pollut. Health1:19-27.

Kelly, G.; Bennion, H.; Cox, E.J.; Goldsmith,B.; Jamieson, J.; Juggins, S.; Mann, D.G. and Telford, R.J. 2005. Common freshwater diatoms of Britain and Ireland: an interactive key. Environment Agency, Bristol. Retrieved 21 November 2016.

Kociolek, P. 2011. Nitzschia sigma In Diatoms of the United States. Retrieved November 27, $\quad 2016$, from ht t p : / / westerndiatoms.colorado.edu/taxa/speci es/nitzschia_sigma1.

Krammer, K. and Lange-Bertalot, H. 1991. Bacillariophyceae 3. Teil: Centrales, Fragilariaceae, Eunotiaceae. Süßwasserflora von Mitteleuropa 2/3, Gustav Fischer Verlag. Jena 576pp.

Kwandrans, J. 2007. Diversity and ecology of benthic diatom communities in relation to acidity, acidification and recovery of lakes and rivers .Diatom Monographs 9: 1-169.

Lange-Bertalot, H. and Metzeltin, D. 1996. Oligotrophie-Indikatoren. 800 Taxa repräsentativ für drei diverse Seen-Typen. Kalkreich-oligodystroph-schwach gepuffertes Weichwasser. In: LangeBertalot, H. (ed.): Iconographia diatomologica - Annotated diatom micrographs. Vol. 2. Ecology-DiversityTaxonomy - 1-390pp., Koeltz Scientific Books, Königstein, Germany.

Levkov, Z.; Krstić, S. and Noveska, M. 2000. Valorisation of Shara Mountain lakes using diatom flora compositions. Ekologija i zastita na zivotnata sredina. 7 (1-2): 15-32.

Levkov, Z.; krstić, S.; Nakov, T. and Melovski 1, J. 2005. Diatom assemblages on Shara and Nidze Mountains, Macedonia. Nova Hedwigia 83: 501-537.

Liu, Y.; Wang, Q. and Fu, C. 2011. Taxonomy and distribution of diatoms in the genus Eunotia from the Da'erbin Lake and Surrounding Bogs in the Great Xing'an 
Mountains, China. Nova Hedwigia 92 (1-2): 205-232

Mayama, S. and Kobayasi, H. 1991. Observations of Eunotia arcus Ehr., type species of the genus Eunotia (Bacillariophyceae). Japanese Journal of Phycology (Sôrui). 39: 131-141.

Metzeltin, D. and Witkowski, A. 1996. Diatomeen der Bären-Insel. Süsswasser- and marine Arten.- In: Lange-Bertalot, H. (ed.): Iconographia diatomologica. Annotated diatom micrographs. Vol. 4. EcologyHydrology-Taxonomy. Koeltz Scientific Books, Koenigstein, Germany -3-232pp.

Ortiz-lerin, R. and Cambra, J. 2007. Distribution and taxonomic notes of Eunotia Ehrenberg 1837 (Bacillariophyceae) in rivers and streams of Northern Spain. Limnetica 26 (2): 415-434.

Otu, M., and Spaulding, S. 2011. Chamaepinnularia mediocris In Diatoms of the United States. Retrieved October 22, 2016.from http://westerndiatoms.colorado.edu/tax a/species/chamaepinnularia_mediocris)

Patrick, R. and Reimer, C.W. 1966. The diatoms of the United States exclusive of Alaska and Hawaii. Vol. 1- Monographs Academy of Natural Sciences, Philadelphia, 688pp.

Patrick, R., and Reimer, C.W. 1975. The diatoms of the united states exclusive of Alaska and $\mathrm{Hawaii}$ Vol. 2, Part 1-Monographs, Academy of Natural Sciences, Philadelphia, 213pp.

Pavlov, A. and Levkov, Z. 2013. Diversity and distribution of taxa in the genus Eunotia Ehrenberg (Bacillariophyta) in Macedonia. Phytotaxa, 86 (1): 1-117.

Perera, P. and Yatigammana, S.K. 2015. Freshwater Diatoms as Proxies of Assessing Environmental Changes in Reservoirs of Sri Lanka. International Journal of Earth Sciences and Engineering 8(2): 417-423.

Pierre, J. F. 1996. Communaut'e algale et acidit'e des ruisseaux du massif vosgien. Bull. Acad. Soc. Lor. Sci., 35:139-156.

Prescott, G.W. 1982. Algae of the Western Great Lakes Area with an Illustrated Key to the Genera of Desmids and Freshwater Diatoms. 1st Edn., Brown Co. Publishers, Dubuque, Iowa, $977 \mathrm{pp}$.

Potapova, M. 2009. Achnanthidium minutissimum -
In Diatoms of the United States. Retrieved October 22, 2016, from http://westerndiatoms.colorado.edu/tax a/species/Achnanthidium_minutissimu $\mathrm{m})$

Round, F.E.1991. Diatoms in river watermonitoring studies. J. Appl. Phycol. 3: 129.

Ruhland, K.M.; Smol, J.P.; Wang, X. and Muir, D.C.G. 2003. Limnological characteristics of 56 lakes in the central Canadian Arctic tree line region. Journal of Limnology 62: 927.

Shekhar, R.T.; Kiran, B.R.; Puttaiah e, T.; Shivaraj, Y. and Mahadevan, K.M. 2008. Phytoplankton as index of water quality with reference to industrial pollution. Journal of Environmental Biology, 29:233236.

Spaulding, S. and Edlund, M. 2008. Eolimna - In Diatoms of the United States. Retrieved October 22, 2016, from http:// westerndiatoms.colorado.edu/taxa/genu s/Eolimna)

Spaulding, S. A.; O'ney, S. and Hermann, K. 2008. "Visual Impacts of Stalk Forming Diatoms in Grand Teton National Park," University of Wyoming National Park Service Research Center Annual Report: Vol. 31, Article 9.Available at: http://repository.uwyo.edu/uwnpsrc_re ports/vol31/iss1/9.

Tariq-Ali, S.; A. Zarina, A.; Masud-ul-Hasan, I. and Mustafa Shameel 2006. Diversity of Pinnularia (Bacillariophyta) in the NorthEastern areas of Pakistan. Pak. J. Bot., 38(4): 1249-1255.

Veselá, J. and Johansen, J.R. 2014. Three new Eunotia (Bacillariophyta) species from Acadia National Park, Maine, USA. Phytotaxa, 175 (4):181-200, Available at: <http://biotaxa.org/Phytotaxa/article/ view/phytotaxa.175.4.1>. Date accessed: 14 Oct. 2016. doi:http://dx.doi.org/ 10.11646/phytotaxa.175.4.1.

Wehr, J. and Sheath, R.G. 2003. Freshwater Algae of North America: Ecology and Classification Academic Press, 917pp.

Whitford, L. A., and Schumacher, G. J. 1973. A manual of fresh water algae Spark Press, Raleigh, N.C., 324pp.

Williams, L. 2008. "Okomu National Park". 
Nigeria: the Bradt travel guide. Bradt Travel Guides ISBN 1-84162-239-7. - 191p. Retrieved 24 August 2016.

Woodell, J. 2015. Placoneis gastrum - In Diatoms of the United States. Retrieved October 22, 2016, from http://westerndiatoms. colorado.edu/taxa/species/placoneis_gastr um)

Zhang, W.; Xinq, J.; Kociolek, P.; Wang, L. and Zhang, R. 2016. Oricymba xianjuensis sp. nov., a new freshwater diatom (Bacillariophyceae) from Xianju National Park (Zhejiang Province, China), Phytotaxa 272, (2):134-140, Available at: <http://biotaxa.org/Phytotaxa/article/ view/phytotaxa.272.2.4>. Date accessed: 14 Oct. 2016. doi:http://dx.doi.org /10.11646/phytotaxa.272.2.4. 